American Journal of Pharmaceutical Education 2019; 83 (9) Article 7460.

\title{
RESEARCH
}

\section{Analysis of Educational Debt and Income Among Pharmacists and Other Health Professionals}

\author{
Marie A. Chisholm-Burns, PharmD, MPH, MBA, ${ }^{a}$ Christina A. Spivey, PhD, ${ }^{\text {a }}$ Sara Stallworth, \\ Joshua Graff Zivin, $\mathrm{PhD}^{\mathrm{b}}$ \\ ${ }^{a}$ University of Tennessee Health Science Center College of Pharmacy, Memphis, Tennessee \\ ${ }^{\mathrm{b}}$ University of California San Diego, School of Global Policy and Strategy, San Diego, California \\ Submitted December 7, 2018; accepted March 20, 2019; published November 2019.
}

Objective. To evaluate educational debt-to-income trends in pharmacy, dentistry, medicine, optometry, and veterinary medicine in the United States from 2010 to 2016.

Methods. A retrospective analysis of educational debt and income for selected health professions was conducted. Data on student loan debt were collected from professional organizations and data on income were collected from the American Community Survey. Ratios of the mean educational debt of graduating students to the median annual income for their respective profession were calculated for 2010 through 2016. Average change per year in debt, income, and debt-to-income ratio were calculated.

Results. Debt-to-income ratios for all selected health professions except medicine exceeded $100 \%$. For physicians, debt-to-income ratios ranged from $89 \%$ to $95 \%$. On average, physicians $(-0.3$ percentage point) and optometrists (- 0.5 percentage point) had negative changes in their debt-to-income ratios from 2010 to 2016. Average increases per year in debt-to-income ratio of veterinarians, pharmacists, and dentists were 5.5, 5.7, and 6.0 percentage points, respectively. From 2010 to 2016, dentists had the largest average increase per year in debt $(\$ 10,525)$, while physicians had the largest average increase per year in income (\$6667) and a minimal average debt increase per year (\$5436). Pharmacists had the second largest average increase per year in debt (\$8356).

Conclusion. Educational debt-to-income ratios in the United States increased considerably over the past decade among pharmacists, dentists, and veterinarians and can negatively impact health professionals as well as patient care. Innovative strategies are needed to alleviate the educational debt burden. Keywords: health professions, income, student loan debt

\section{INTRODUCTION}

Student loan debt in the United States has more than tripled since 2006, and as of the third quarter of 2019, stands at over $\$ 1.6$ trillion. ${ }^{1}$ On average, college students accrue greater than $\$ 37,000$ in educational loan debt by the time they complete their undergraduate program of study. ${ }^{2}$ If students then choose to pursue professional, doctorate-level education in the health sciences, educational debt can increase exponentially. Total student loan debt for pharmacy, dental, medical, optometry, and veterinary medicine degree programs can exceed $\$ 100,000$ or even $\$ 200,000 .^{3}$ Such loans

Corresponding Author: Marie Chisholm-Burns, University of Tennessee Health Science Center College of Pharmacy, 881 Madison Ave., Ste. 264, Memphis, TN 38163. Tel: 901-4487141. Fax: 901-448-7053. Email: Mchisho3@uthsc.edu.

Conflicts of Interest: Marie Chisholm-Burns serves on the board of directors for ACPE. This manuscript does not represent $\mathrm{ACPE}$ or the board's opinions or views. are driven by familiar factors: tuition, fees, and costs of living. According to the Organization for Economic Cooperation and Development, average postsecondary tuition costs are greater in the United States than in almost any other of its member countries. ${ }^{4}$ Tuition increases in recent years have been spurred by cuts in state funding for higher education and rising programmatic and operations expenses. ${ }^{5}$

With soaring levels of educational loan debt hampering current and future generations of college graduates, it is imperative to consider the implications of this increasing financial burden on health professionals. Potential consequences include reduced ability to reach financial independence, delayed home ownership, postponement in starting a family, and hindered ability to save for retirement. ${ }^{6,7}$ Mackenzie further highlights the profound negative impact that accumulation of educational loan debt can have on a household's lifetime standard of living. ${ }^{8}$ With each incremental increase in student loan debt, total 


\section{American Journal of Pharmaceutical Education 2019; 83 (9) Article 7460.}

lifetime expenditure capacity of a household permanently decreases. $^{8}$ Several studies among students have also linked increased financial debt, or financial strain, to higher levels of perceived stress and/or psychological distress, which in turn are associated with negative health outcomes and poorer academic performance..$^{9-21}$

Because of concerns about acquiring or accumulating further educational debt and the enumerated potential consequences, individuals may be more hesitant to pursue a career in health care. For example, student pharmacists have reported that the rising cost of tuition is a barrier to applying to pharmacy school. ${ }^{22}$ The choice to avoid pharmacy (or other health professions) school because of cost could disproportionately impact low-income individuals and may influence the diversity of the student body. Additionally, the increasing incidence of student loan burden among health professionals may inadvertently contribute to worsening health care disparities in the United States. ${ }^{23}$ To explain further, the Institute of Medicine confirmed that increased diversity among health professionals is linked to improved access among minority patients, with minority providers being more likely to practice in minority and underserved communities. ${ }^{24}$ A critical risk for these already vulnerable communities is that as educational costs and subsequent financial debt escalate, lower-income and underrepresented minorities may shy away from pursuing health professions education and careers. ${ }^{25}$ Higher debt may also discourage individuals from seeking primary care careers. A survey of US medical students found that those with higher educational debt were more likely to pursue higher paid specialties, less likely to pursue primary care, and less likely to practice in medically underserved regions. ${ }^{7}$ Although this gap of primary care physicians may provide a niche for other health professionals, it raises concerns and increases risk of health care disparities. Therefore, unintended consequences of high educational debt may be far-reaching and profound, as access to primary care dwindles and disparities in underserved communities are exacerbated.

Rising educational loan debt as a result of increased costs of obtaining pharmacy, medical, dental, optometry, and veterinary medicine degrees is thus a source of deepening concern. In 2013, Asch and colleagues examined debt-toincome ratios of medical specialties and other occupations, and questioned whether we were in a medical education bubble market. ${ }^{26}$ They found that from 1996 to 2010, growth in student loan debt generally outpaced income growth across health and other professions. ${ }^{26}$ However, these trends appeared to slow and even reverse for medicine and dentistry near the end of the study period. ${ }^{26}$ The question that motivated our analysis was whether these downward trends in medicine and dentistry were indicative of reduced debt-to- income ratios, or at least minimal increases or stabilization, for the health professions including pharmacy. Therefore, the objective of this study was to evaluate educational debt-toincome trends in pharmacy, dentistry, medicine, optometry, and veterinary medicine from 2010 to 2016, and consider implications for future health professions students pursuing education for a career in health care.

\section{METHODS}

A retrospective analysis of educational debt and income data for the health professions of pharmacy, dentistry, medicine, optometry, and veterinary medicine was conducted. These professions were selected for inclusion because of their notably high educational debt load compared to other health professions, such as nursing. The methods employed were similar to those of Asch and colleagues, who collected data on median income for the years 1996 through 2010 for medicine and medical specialties, as well as other professions (eg, pharmacy, optometry, dentistry, law, and business, among others), from the Medical Group Management Association, American Dental Association, and the Current Population Survey. ${ }^{26}$ They also collected data on average student loan debt for the same time period from the Association of American Medical Colleges, American Dental Education Association, American Bar Association, American Association of Colleges of Pharmacy, and National Center for Education Statistics. ${ }^{26}$ They then calculated the ratio of debt-toincome for each medical specialty and occupation of interest. $^{26}$

Data were collected on mean (or median if mean was not available) student loan debt for the years 2010 through 2016 from surveys conducted by the Association of American Medical Colleges, American Dental Education Association, Association of Schools and Colleges of Optometry, American Association of Colleges of Pharmacy, and Association of American Veterinary Medical Colleges. ${ }^{27-31}$ Data were primarily available via the websites of these associations. When not available on the website, data requests were submitted to the associations via personal communication. Data were collected on median income from the American Community Survey for 2010 to 2016. The American Community Survey is conducted annually by the US Census Bureau to collect national data on demographics and other population characteristics (eg, economic). At the time of the analysis, income data were available only through 2016. As data collection was limited to published aggregate data, this was not considered human subjects research, and therefore institutional review board approval was not needed.

Ratio of mean educational debt of graduating students to the median annual income of their profession was 


\section{American Journal of Pharmaceutical Education 2019; 83 (9) Article 7460.}

calculated. ${ }^{26}$ Debt-to-income ratios greater than $100 \%$ indicated debt was greater than income, while ratios less than $100 \%$ indicated income was greater than debt. A measure of market economy, debt-to-income ratios were selected as the unit of analysis as they align better than more elaborate calculations with how students make decisions regarding financing education. ${ }^{26}$ For all professions, mean student loan debt during professional school was compared to median wages for all years, with two exceptions. For veterinarians, median debt was compared to median wages for all years, as mean debt was not available. For physicians, mean debt was compared to median wages for all years except 2016. In 2016, median debt was compared to median wages, as mean debt was not available. These ratios are produced with certain caveats: they only include debt accumulated during professional school and they do not take into account the timing of the health care graduate entering the workforce. The analysis was generally based on the work of Asch and colleagues, ${ }^{26}$ with some variation due to data availability and varying logistics. We also calculated average change per year in debt, income, and debt-to-income ratio for each health profession of interest between 2010 and 2016 .
Data analysis was conducted using SPSS Statistics 25.0 (IBM, Armonk, NY).

\section{RESULTS}

As displayed in Figure 1, with the exception of medicine, debt-to-income ratios for each health profession consistently exceeded $100 \%$ between 2010 and 2016. Debt-to-income ratios for physicians ranged from $89 \%$ to $95 \%$ during the study period. The profession with the second lowest debt-to-income ratios was pharmacy, with ratios ranging from $107 \%$ to $141 \%$. Ratios were highest for veterinarians throughout the entire study period, remaining above 160\% from 2011 onward.

The average change per year in debt, income, and debt-to-income ratio of each health profession between 2016 and 2010 are presented in Table 1. On average, physicians (- 0.3 percentage point) and optometrists ( -0.5 percentage point) had negative changes in their debt-toincome ratios between the two years. In contrast, average increases per year in debt-to-income ratio of veterinarians, pharmacists, and dentists were 5.5, 5.7, and 6.0 percentage points, respectively. Dentists had the largest average increase per year in debt $(\$ 10,525)$ followed by

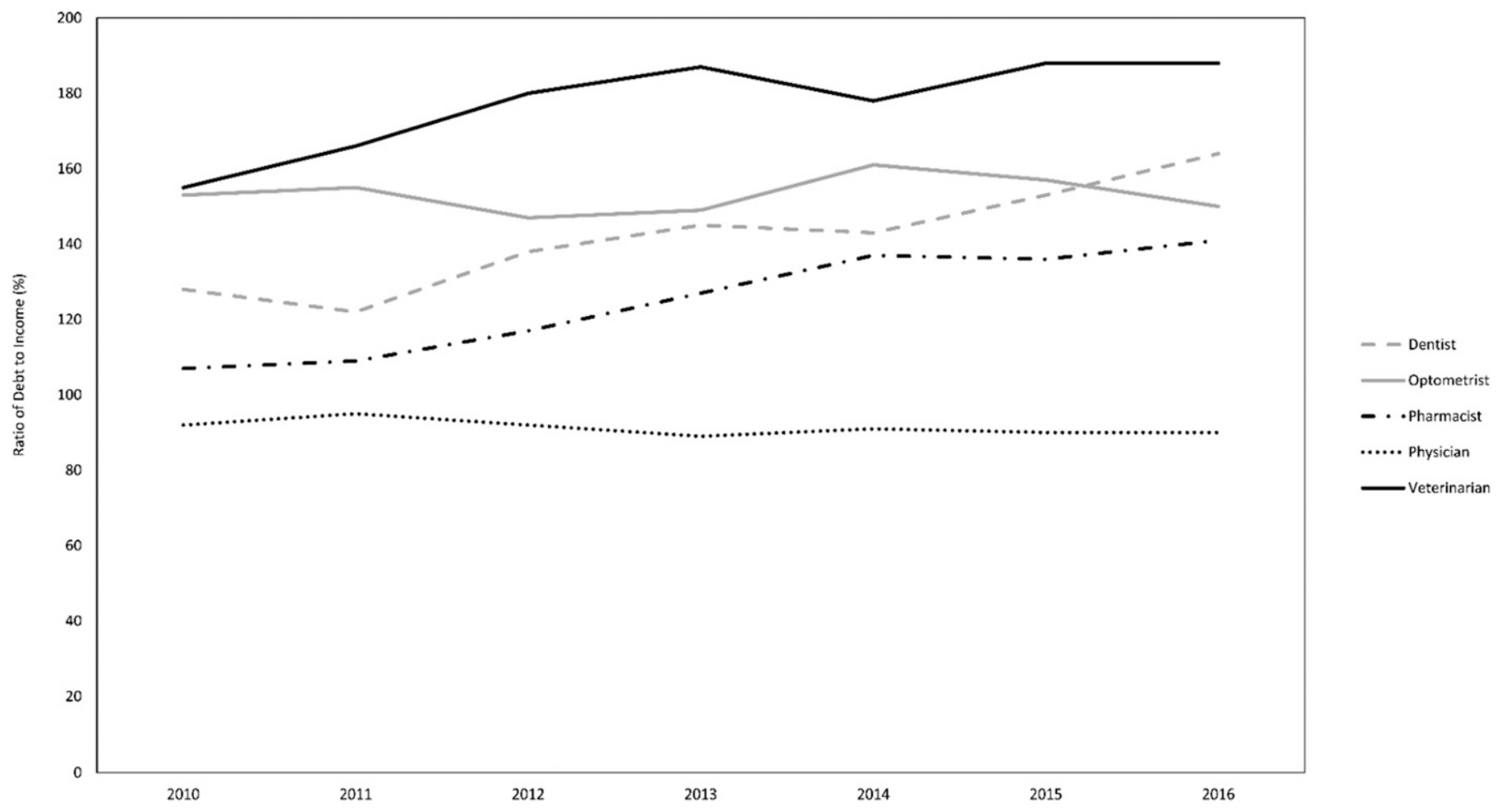

Figure 1. Ratios of debt to income, according to health profession. Data on median income were collected from the American Community Survey. At the time of the analysis, income data were only available through 2016. Data on average student loan debt were collected from surveys conducted by the Association of American Medical Colleges, American Dental Education Association, Association of Schools and Colleges of Optometry, American Association of Colleges of Pharmacy, and Association of American Veterinary Medical Colleges. 
American Journal of Pharmaceutical Education 2019; 83 (9) Article 7460.

Table 1. Comparison of 2016 and 2010 Student Loan Debt, Income, and Debt-to-Income Ratios Across Health Professions

\begin{tabular}{|c|c|c|c|}
\hline Profession & Student Loan Debt, $\$^{a}$ & Income, $\$^{\mathbf{b}}$ & Debt-to-Income Ratio, $\%$ \\
\hline \multicolumn{4}{|l|}{ Dentist } \\
\hline 2016 & 229,417 & 140,000 & 164 \\
\hline 2010 & 166,265 & 130,350 & 128 \\
\hline ACPY & 10,525 & 1608 & $6^{\mathrm{e}}$ \\
\hline \multicolumn{4}{|l|}{ Optometrist } \\
\hline 2016 & 163,980 & 109,100 & 150 \\
\hline 2010 & 131,599 & 86,000 & 153 \\
\hline$A C P Y^{d}$ & 5397 & 3850 & $-0.5^{\mathrm{e}}$ \\
\hline \multicolumn{4}{|l|}{ Pharmacist } \\
\hline 2016 & 157,425 & 112,000 & 141 \\
\hline 2010 & 107,292 & 100,250 & 107 \\
\hline$A C P Y^{d}$ & 8356 & 1958 & $5.7^{\mathrm{e}}$ \\
\hline \multicolumn{4}{|l|}{ Physician } \\
\hline 2016 & 180,000 & 200,000 & 90 \\
\hline 2010 & 147,383 & 160,000 & 92 \\
\hline$A C P Y^{d}$ & 5436 & 6667 & $-0.3^{\mathrm{e}}$ \\
\hline \multicolumn{4}{|l|}{ Veterinarian } \\
\hline 2016 & 159,923 & 85,000 & 188 \\
\hline 2010 & 124,191 & 80,000 & 155 \\
\hline$A C P Y^{d}$ & 5955 & 833 & $5.5^{\mathrm{e}}$ \\
\hline
\end{tabular}

${ }^{a}$ Data on average student loan debt were collected from surveys conducted by the Association of American Medical Colleges, American Dental Education Association, Association of Schools and Colleges of Optometry, American Association of Colleges of Pharmacy, and Association of American Veterinary Medical Colleges

${ }^{\mathrm{b}}$ Data on median income were collected from the American Community Survey

${ }^{c}$ Debt-to-income ratio, expressed as percentage, indicates change in debt relative to change in income per year over a given time period, in this case, 6 years. Numbers greater than 100\% indicate debt exceeds income, while those less than 100\% indicate income exceeds debt

${ }^{\mathrm{d}}$ Average change per year (ACPY) between the two years of 2010 and 2016

e Percentage points of ACPY between the debt-to-income ratios of 2010 and 2016

pharmacists (\$8356), while physicians and optometrists had the smallest average changes (\$5436 and \$5397, respectively). Physicians had the largest average increase per year in income (\$6667), while veterinarians had the smallest average increase $(\$ 833)$.

\section{DISCUSSION}

In $2015-2016$, approximately $75 \%$ of graduates of health professions doctorate programs (ie, pharmacy, chiropractic, dentistry, optometry, podiatry, and veterinary medicine) and $81 \%$ of medical school graduates had federal and/or private student loans. ${ }^{3}$ Average (or median for medicine and veterinary medicine) student loan debt in 2016 exceeded $\$ 150,000$ for each of the five health professions of pharmacy, dentistry, medicine, optometry, and veterinary medicine, with dentistry being the only health profession to exceed $\$ 200,000$. Interest rates on federal student loans range from approximately $5 \%$ to $8 \%$, depending on type of loan, with repayment periods typically of 10 to 25 years. ${ }^{32,33}$ As a rough example, monthly repayments over 10 years for a $\$ 200,000$ federal student loan at $6 \%$ interest would be approximately $\$ 2220$ per month, and this payment would need to be made in conjunction with other living expenses.

Given increasing educational costs and the growing student debt crisis, the objective of the current study was to examine changes in educational debt-to-income trends among the five selected health professions between 2010 and 2016. In their analysis of educational debt from 1996 to 2010, Asch and colleagues reported notable increases in the debt-to-income ratios of the five selected professions, particularly veterinary medicine and optometry. ${ }^{26}$ While those trends continued for pharmacy, veterinary medicine, and dentistry in the current study, medicine and optometry, to an extent, were more stable. Specifically, we found that educational debt-to-income ratios for 2016 were less favorable than those for 2010 for pharmacists, dentists, and veterinarians but not for physicians and optometrists. When examining changes in debt and income separately, increases in debt far outpaced increases in income for dentistry, pharmacy, and veterinary medicine. For example, we found that between 2010 and 2016, the average annual increase in student loan debt for pharmacists was $\$ 8356$, while average growth in 


\section{American Journal of Pharmaceutical Education 2019; 83 (9) Article 7460.}

income was only $\$ 1958$. In contrast, the gap between debt and income on average per year was much narrower for optometry as debt increased by $\$ 5397$ and income increased by $\$ 3850$. The negative changes noted in medicine's debt-to-income ratio when comparing 2016 and 2010 indicate that income growth kept pace with, and even surpassed, growth in debt, which is further supported by the average changes in debt (\$5436) and income (\$6667) individually.

Although medicine's debt-to-income ratios are consistently less than those for the other health professions of interest, trends since 2014 suggest medical school debt is increasing. Between 2014 and 2016, median educational debt increased by $\$ 7000$, while between 2016 and 2018 it increased by $\$ 15,000$. Among medical school graduates in 2018, more than $70 \%$ had student loans for medical school, and more than one quarter had student loans totaling between $\$ 200,000$ and $\$ 299,000$. $^{27}$ If income growth tightens to the point of falling behind increases in educational debt, medicine could experience the same serious consequences some of the other selected health professions are currently facing, such as a shrinking applicant pool. In the 2017-2018 academic year, medicine experienced its first drop in a decade in the number of medical school applicants from the previous year $(-2.6 \%)$, though there was a small uptick in 2018$2019 .^{34}$ This drop is only slightly lower than the drop in pharmacy applicants between 2016-2017 and 2017-2018 $(-3.1 \%)$ and higher than the drop in dentistry applicants $(-1.5 \%) .{ }^{35,36}$ Additionally, health professions students and graduates are susceptible to personal risks (psychological distress, burnout, decreased quality of life, and decreased satisfaction with work-life balance, among others) associated with educational debt, which may worsen should debt-to-income ratios increase. ${ }^{9-14,20,37}$

As previously noted, educational debt burden may also contribute to reductions in patient access and increases in health disparities. Rohlfing and colleagues reported that students with higher levels of financial debt were more likely to pursue careers in specialized fields rather than primary care. ${ }^{7}$ However, specialty fields also face challenges resulting from educational loan debt. For example, Ikonomidis and colleagues reported that the Society of Thoracic Surgeons is predicting shortages in cardiothoracic surgeons as educational debt and years of required training increase. ${ }^{38}$ Rohlfing and colleagues and Goodfellow and colleagues also found that physicians were less likely to practice in medically underserved regions because of significant differences in income. ${ }^{7,39}$ Likewise other health professionals may choose to practice in higher-paying regions that are not considered medically underserved. This phenomenon may ultimately lead to an increase in existing health care disparities across rural communities, medically underserved communities, and among minority populations within the United States.

Generally, increasing student loan debt is a reaction to the rising costs of education and living expenses. Cain and colleagues noted that the cost of pharmacy education, for example, increased an estimated 54\% between 2004 and 2014 (a 10-year period). ${ }^{40}$ In our study, student loan debt increased $47 \%$ from 2010 to 2016 (a six-year period). Other factors contributing to the growing costs of health professions education include reduced state funding and increased compliance and infrastructure/operations. Another possible factor related to increased debt for graduate and professional students is that, as of the 2012-2013 school year, advanced degree students were no longer eligible for subsidized federal loans. ${ }^{41}$ Per the Federal Student Aid Office of the US Department of Education, this type of loan is designed to help students with financial need, and the federal government pays for the interest on these loans while undergraduate students are enrolled in school at least half-time, for six months after leaving school, and during any deferment period such as returning to school. ${ }^{33}$ Because subsidized federal loans are no longer available for graduate or professional students, any loans taken out by pharmacy or other health professions students during their professional program will accrue interest during their time in school, resulting in higher loan balances by the time they graduate. These various issues have resulted in a "perfect storm" of circumstances exacerbated by students borrowing the maximum allowable amount and the lack of attention (or simply not knowing what to do) by college administrations to student loans. The result is a growing state of educational debt crisis for health professions students.

With continued growth of accumulated educational debt among students in health professions comes overarching concerns for the future viability of these professions. As increasing tuition expenses plunge current students further and further into debt, the risk of financial overburden may outweigh prospective students' perceived return on their investment toward a professional doctorate in a health profession. This could result in reduced numbers of individuals willing to pursue health professions careers and a corresponding decrease in the supply of health professionals. A smaller supply of providers will, in turn, drive up health care costs and place an even greater strain on access to care for individuals who struggle to pay for services. Simply put, patients will suffer.

Colleges of pharmacy and other health professions colleges have an obligation to reduce the financial burden that tuition and fees place upon students. To accomplish 


\section{American Journal of Pharmaceutical Education 2019; 83 (9) Article 7460.}

this and to continue attracting the best and brightest students, colleges of pharmacy, dentistry, medicine, optometry, and veterinary medicine should consider implementing debt minimization strategies. One approach we implemented at the University of Tennessee Health Science Center College of Pharmacy was a drastic minimization of tuition increases and even reductions in tuition. Additionally, medical schools across the country are deploying notable programs to address student debt that may serve as examples for health professions colleges across the United States. ${ }^{42}$ Based on a multimillion-dollar philanthropic gift, Columbia University's medical school is eliminating loans from student financial aid packages, with loans being replaced by scholarships and grants. Similarly, New York University's medical school recently announced that it would provide all students full-tuition scholarships as a result of extensive fundraising. ${ }^{43}$

The following are three additional strategies that health professions schools should consider implementing. First, they should consider offering lower tuition rates, either by cost savings derived from changing how the curriculum is delivered, or by requiring graduates to provide service in select fields (eg, family medicine) or geographic areas. ${ }^{42}$ Second, they should participate in scholarship, loan, and loan repayment programs offered by the Health Resources and Services Administration, including scholarships and loans for disadvantaged health professions students; loan programs for students who commit to primary care practice for a certain period of time; loan repayment for health professionals in the Indian Health Service; and National Health Service Corps loan repayment for qualifying individuals. ${ }^{44,45}$ Third, they should offer or assist students with using loan assistance repayment programs or loan forgiveness programs, such as the Public Service Loan Forgiveness Program offered by the US Department of Education. Such programs often require service in underserved communities and are associated with working long-term in these communities. They are also effective in bolstering physician recruitment and retention. ${ }^{42,46,47}$

Although these various mechanisms for reducing student debt may fall short in addressing some expenses, such as program fees, textbook costs, and room and board expenses, they represent an important advance in alleviating the financial burden associated with health professions education. Prior studies also suggest that moving pharmacy education (and likewise, other health professions programs) toward a more efficient model, defined as a model in which the financial burden on students is reduced, would require limiting unnecessary costs, identifying areas of overspending, and implementing cost containment strategies. ${ }^{48,49}$
In addition to reducing the burden of high tuition, colleges of pharmacy and other health professions have an opportunity to help students learn about finances. ${ }^{50} \mathrm{By}$ adding a personal finance course or group activities focused around topics in personal financial management, such as budgeting, savings, and managing debt, colleges will help students understand the true cost of taking out loans. Also, health professions colleges must offer financial counseling services to students and help them understand the repayment process. Ideally, students would have these courses and instruction during high school and as an undergraduate student (which is when such knowledge development would likely be most helpful as many students begin accumulating high educational debt before they attend professional school). Because contemplation and greater knowledge about loans are associated with lower student debt, total number of federal loans borrowed, and total student loan debt among pharmacy students, additional resources should be made available to compare loan types and interest rates, and improve understanding of strategies for paying back student loans (eg, making payments above the minimum amount due each month). ${ }^{21,50,51}$

Because data were not available for some health professions, the analysis included debt that students accumulated during professional school but not debt they accumulated during their undergraduate education, which would add to a student's financial burden. Additionally, the analysis did not account for income variability based on postgraduate training and the timing of when the health care graduate entered the workforce. Because of the variability in factors such as residency requirements, length, and availability, a standard measure of income across professions, the American Community Survey, was selected for analysis. Future studies should look at the potential impact of postgraduate training on educational debt-to-income considerations across health professions.

\section{CONCLUSION}

Increasing tuition and heavier educational loan debt burden has created a state of crisis. The majority of students in the health professions of pharmacy, medicine, dentistry, optometry, and veterinary medicine accrue large amounts of total educational debt by the time they graduate, typically between $\$ 100,000$ and $\$ 200,000$. Unfortunately, changes in income have not kept pace with debt for pharmacy, dentistry, and veterinary medicine. Medicine, and to some degree optometry, have fared better, though warning signs have surfaced. The financial burden associated with pursuing a health professions education may deter individuals from a health care career, potentially resulting in workforce shortages, which would 


\section{American Journal of Pharmaceutical Education 2019; 83 (9) Article 7460.}

have dire consequences for already underserved communities. To alleviate student loan debt burden among health professionals, and mitigate the possible negative consequences of that debt, long-term creative and targeted solutions will be necessary.

\section{References}

1. Board of Governors of the Federal Reserve System (US). Student loans owned and securitized, outstanding [SLOAS], retrieved from FRED, Federal Reserve Bank of St. Louis. https://fred.stlouisfed.org/series/ SLOAS. Updated November 7, 2019. Accessed November 20, 2019. 2. Hess A. Here's how much the average student loan borrower owes when they graduate. CNBC; https://www.cnbc.com/2018/02/15/ heres-how-much-the-average-student-loan-borrower-owes-whenthey-graduate.html. February 15, 2018. Accessed March 1, 2019. 3. McFarland J, Hussar B, Wang X, et al. The condition of education 2018 (NCES 2018-144). US Department of Education. Washington, DC: National Center for Education Statistics; May 2018. https:// nces.ed.gov/pubs2018/2018144.pdf. Accessed March 1, 2019. 4. Organization for Economic Co-operation and Development. Education at a glance 2017: OECD indicators. Paris: OECD Publishing; 2017. http://dx.doi.org/10.1787/eag-2017-en. Accessed March 1, 2019.

5. Phillips M, Russell K. The next financial calamity is coming. Here's what to watch. The New York Times. September 12, 2018. https://www.nytimes.com/interactive/2018/09/12/business/the-nextrecession-financial-crisis.html. Accessed March 1, 2019.

6. Ulbrich TR, Kirk LM. It's time to broaden the conversation about the student debt crisis beyond rising tuition costs. Am J Pharm Educ. 2017;81(6):101.

7. Rohlfing J, Navarro R, Maniya OZ, Hughes BD, Rogalsky DK. Medical student debt and major life choices other than specialty. Med Educ Online. 2014;19:25603. doi: 10.3402/meo.v19.25603.

8. Mackenzie GA. The financial impact of student debt on working and retired Americans. Society of Actuaries; August 2017. https:// www.soa.org/research-reports/2017/financial-impact-student-debt/. Accessed March 1, 2019.

9. Boyles JD, Ahmed B. Does student debt affect dental students' and dentists' stress levels? Br Dent J. 2017;223:601-606.

10. Gregory K, Matthew S, Baguley J. Analysis of the costs of veterinary education and factors associated with financial stress among veterinary students in Australia. Aust Vet J. 2017;96:11-16. 11. Morra DJ, Regehr G, Ginsburg S. Anticipated debt and financial stress in medical students. Med Teach. 2008;30:313-315.

12. Hayes A, Hoover JN, Karunanayake CP, Uswak GS. Perceived causes of stress among a group of Western Canadian dental students. BMC Res Notes. 2017;10(1):714. doi: 10.1186/s13104-017-2979-9.

13. McNeeley MF, Perez FA, Chew FS. The emotional wellness of radiology trainees. Acad Radiol. 2013;20:647-655.

14. Collier VU, McCue JD, Markus A, Smith L. Stress in medical residency: status quo after a decade of reform? Ann Intern Med. 2002;136:384-390.

15. Silverstein ST, Kritz-Silverstein D. A longitudinal study of stress in first-year dental students. J Dent Educ. 2010;74:836-848.

16. Crego A, Carillo-Diaz M, Armfield JM, Romero M. Stress and academic performance in dental students: the role of coping strategies and examination-related self-efficacy. J Dent Educ. 2016;80:165-172.

17. Kötter T, Wagner J, Brüheim L, Voltmer E. Perceived medical school stress of undergraduate medical students predicts academic performance: an observational study. BMC Med Educ. 2017;17(1):256. doi: 10.1186/s12909-017-1091-0.

18. Sohail N. Stress and academic performance among medical students. J Coll Physicians Surg Pak. 2013;23:67-71.

19. Elani HW, Allison PJ, Kumar RA, Mancini L, Lambrou A, Bedos C. A systematic review of stress in dental students. J Dent Educ. 2014;78:226-242.

20. Jackson ER, Shanafelt TD, Hasan O, Satele DV, Dyrbye LN. Burnout and alcohol dependence among U.S. medical students. Acad Med. 2016;91:1251-1256.

21. Chisholm-Burns MA, Spivey CA, Jaeger MC, Williams J. Associations between pharmacy students' attitudes toward debt, stress, and student loans. Am J Pharm Educ. 2017;81(7):Article 5918. 22. Alonzo N, Bains A, Rhee G, et al. Minority trends and barriers in pharmacy school enrollment. Am J Pharm Educ. 2019;83(7):Article 6925.

23. Zimmerschied C. How med student loan burdens can deepen health disparities. American Medical Association (AMA) Wire. April 27, 2017. https://wire.ama-assn.org/education/how-medstudent-loan-burdens-can-deepen-health-disparities. Accessed March 1, 2019

24. Smedley BD, Butler AS, Bristow LR, eds. In the nation's compelling interest: ensuring diversity in the health-care workforce. Institute of Medicine. Washington, DC: The National Academies Press; 2004. https://www.nap.edu/catalog/10885/in-the-nationscompelling-interest-ensuring-diversity-in-the-health. Accessed March 1, 2019.

25. Jolly P. Medical school tuition and young physicians' indebtedness. Health Aff. 2005;24:527-535.

26. Asch DA, Nicholson S, Vujicic M. Are we in a medical education bubble market? N Engl J Med. 2013;369:1973-1975. 27. Association of American Medical Colleges. Graduation Questionnaire. https://www.aamc.org/data/gq/. Accessed March 1, 2019.

28. American Dental Education Association. Dental School Seniors. https://www.adea.org/data/seniors/. Accessed March 1, 2019. 29. American Association of Colleges of Pharmacy. Graduating Student Survey. https://www.aacp.org/categories/graduating-student. Accessed March 1, 2019.

30. Association of Schools and Colleges of Optometry. Student Data Reports. https://optometriceducation.org/student-data-reports/.

Accessed March 1, 2019.

31. Association of American Veterinary Medical Colleges. Annual Report 2017. http://www.aavmc.org/assets/site_18/files/ annual\%20reports/aavmc-ar-2017-final2.pdf. Accessed March 1, 2019.

32. Federal Student Aid. Interest rates and fees. U.S. Department of Education. https://studentaid.ed.gov/sa/types/loans/interest-rates. Accessed March 4, 2019.

33. Federal Student Aid. Subsidized and unsubsidized loans. US Department of Education. https://studentaid.ed.gov/sa/types/loans/ subsidized-unsubsidized. Accessed March 4, 2019.

34. Association of American Medical Colleges. Table A-7.2: applicants, first-time applicants, acceptees, and matriculants to U.S. medical schools by sex, 2009-2010 through 2018-2019. November 9, 2018. https://www.aamc.org/download/492954/data/

factstablea7_2.pdf. Accessed March 1, 2019.

35. American Association of Colleges of Pharmacy. PharmCAS

Volume Update. June 3, 2018. https://connect.aacp.org/

HigherLogic/System/DownloadDocumentFile.ashx? 


\section{American Journal of Pharmaceutical Education 2019; 83 (9) Article 7460.}

DocumentFileKey=6a11ba93-699f-4f69-833c-8029f54df8fd. Accessed March 1, 2019.

36. American Dental Education Association. Applicants, Enrollees and Graduates. https://www.adea.org/publications-and-data/dataanalysis-and-research/applicants-enrollees-and-graduates.aspx. Accessed March 1, 2019.

37. West CP, Shanafelt TD, Kolars JC. Quality of life, burnout, educational debt, and medical knowledge among internal medicine residents. JAMA. 2011;306:952-960.

38. Ikonomidis JS. The society of thoracic surgeons thoracic surgery practice and access task force: 2014 workforce report. Ann Thorac Surg. 2016;102:2118-2125.

39. Goodfellow A, Ulloa JG, Dowling PT, et al. Predictors of primary care physician practice location in underserved urban or rural areas in the United States: a systematic literature review. Acad Med. 2016;91:1313-1321.

40. Cain J, Campbell T, Congdon HB, et al. Pharmacy student debt and return on investment of a pharmacy education. Am J Pharm Educ. 2014;78(1):Article 5.

41. Baum S, Steele P. Graduate and professional school debt: how much students borrow. AccessLex Institute Research Paper. 2018. https://www.accesslex.org/resources/grad-and-professional-schooldebt-how-much-students-borrow. Accessed May 9, 2019.

42. Powell F. What medical schools are doing to reduce student debt. US News \& World Report. May 29, 2018. https://www.usnews.com/ education/best-graduate-schools/top-medical-schools/articles/201805-29/what-medical-schools-are-doing-to-reduce-student-debt.

Accessed March 1, 2019.
43. Chen DW. Surprise gift: free tuition for all NYU medical students. The New York Times. August 16, 2018. https:// www.nytimes.com/2018/08/16/nyregion/nyu-free-tuition-medicalschool.html. Accessed March 1, 2019.

44. Health Resources and Services Administration. School-Based Scholarships and Loans. March 2018. https://bhw.hrsa.gov/ loansscholarships/schoolbasedloans. Accessed October 23, 2018. 45. Health Resources and Services Administration. Loan Repayment. https://nhsc.hrsa.gov/loan-repayment/eligibility/ index.html. Accessed March 1, 2019.

46. Federal Student Aid. Forgiveness, Cancellation and Discharge. U.S. Department of Education. https://studentaid.ed.gov/sa/repayloans/forgiveness-cancellation. Accessed March 1, 2019.

47. Bärnighausen T, Bloom DE. Financial incentives for return of service in underserved areas: a systematic review. BMC Health Serv Res. 2009;9:86.

48. Mattingly TJ. Is there room for efficiency in pharmacy education? Am J Pharm Educ. 2018;82(9):Article 7271.

49. Duncan W, Bottenberg M, Chase M, et al. An industrial engineering approach to cost containment of pharmacy education. Am J Pharm Educ. 2015;79(9):Article 131.

50. Ulbrich TR, Kirk LM. It's time to broaden the conversation about the student debt crisis beyond rising tuition costs. Am J Pharm Educ. 2017;81(6):Article 101.

51. Cain J, Campbell T, Congdon HB, et al. Complex issues affecting student pharmacist debt. Am J Pharm Educ.

2014;78(7):Article 131. 